Endocrinol. Japon. 1964, 11 (2), 101 111

\title{
A DOUBT FOR THE CLASSIFICATION OF THYROTROPH AND GONADOTROPH IN THE ANTERIOR LOBE OF RAT PITUITARY
}

\author{
FUJIO YOSHIMURA, KANJI HARUMIYA, \\ RYUZO ITO AND NAOZUMI SUZUKI
}

\author{
Department of Histology and Embryology, Jikei-kai \\ School of Medicine, Shiba, Tokyo
}

In the basophile cell in the anterior lobe of rat pituitary two kinds of cells, thyrotroph regarded as the source of TSH and gonadotroph secreting GTH, have been commonly distinguished. Many investigators have held the reconciled view that the independent cell types are conditioned on their shape and stainability. The discriminating points between thyrotroph $(\mathrm{T})$ and gonadotroph $(\mathrm{G})$ which have been accepted are enumerated as follows: 1) $\mathrm{T}$ is polygonal or angular, and $\mathrm{G}$ is spherical or oval (Reese et al., 1943), 2) $\mathrm{T}$ is strongly positive with periodic acid Schiff's reaction(PAS), and stained with aldehyde fuchsin(AF), while $G$ is rather weakly positive with PAS and negative with AF stain (Halmi, 1950 and 1952; Purves and Griesbach, $1951 \mathrm{a}$ and b), 3) When the section was combinedly stained with PAS and methylblue, $\mathrm{T}$ does not react enough on methylblue, being PAS-red, while G is strongly stained with it, respresenting PASpurple tincture (Wilson and Ezrin, 1954). Such a staining affinity of $\mathrm{T}$ and $\mathrm{G}$ on methylblu was not, however, admitted by Purves and Griesbach (1955), Rennels (1956) and Rennels et al. (1956), who divided G into two cells, PAS-red FSH secreting cell and PAS-purple LH secreting one, by PAS-methylblue stain. According to them, the former is spherical, located at the central area of anterior pituitary and participated in the active secretion, while the latter is polygonal, being located at the periphery, and may engage in the inert secretory activity.

The PAS-positive basophile cell is considered in general to be a vehicle of glycoprotein hormone, but the source of simple protein hormone such as growth hormone, ACTH and prolaction is conceived belonging to the another type of cell, although the proof for the fact that ACTH is released out from the basophile cells is now convincing (Marshall, 1951). It is a question whether or not the staining aspect of both cells on $\mathrm{AF}$ and methylblue can manifest the real reflection to the chemical nature of TSH and GTH. At the same time, the distinction in shape between two cells is not always rigidly maintained in all cases. If the intermediate or transitional form is present between $T$ and $G$, the reliance on the classification of them according to the cell-countour will become shaken. Above all, the classification of FSH- and LH-secreting cells which depends upon their staining ability has been confused (Barnett et al., 1956), and further investigation is required for the improvement of this subject.

Received for publication April 16, 1964. 
In the present experiment, the evolutional changes appeared in the anterior lobe of pituitary following the long-term castration. Especially some relationships between the marked changes in basophile cell and the subsequent responses in thyroid and in adrenal cortex were investigated. Evidences were present that the classification of $G$ and $T$ is not reliable, but the monism was led concerning the hormore production in the basophile cell.

\section{MATERIALS AND METHODS}

Sixty male rats of Wistar-Imamichi strain were used in the present investigation. The experimental groups were shown in Figure 2. They were divided into 10 groups which consisted of 3 intact control and 3 castrated rats respectively. The castration was uniformly performed in all experimental animals on the 45th day. The animals in Group 2 to 10 were decapitated respectively at the $10,30,50,55,60,180,240,300$ th, and 421 st postoperative day in the sequence. The days when the animals were sacrificed corresponded to the respective days of age shown in Figure 2. Group 1 was only served as the non-castrated normal control. Rats used were in litter mate, fed with the constant diet prepared in our laboratory. The hypophysis, thyroids and adrenals were fixed with Levi's liquid and Bouin solution. Paraffin-sections of the materials fixed with Levi's liquid were stained with periodic acid Schiff's reaction (PAS) with the counterstain of iron hematoxylin, and with counterstain of methylbue. Bouin fixed materials were stained with aldehyde fuchsin (AF).

\section{RESULTS AND DISCUSSION}

\section{Body-weight and organ-weight}

The increase in body-weight of the normal control rats was illustrated in Figure 1. The value of the body-weight at the respective days of age represented the average of the measurements of 3 animals in the same group. The bodyweight increased following the castration, and the rising gradient became steeper (Fig. 1). The mean value of weights of hypophysis, thyroid and adrenal was shown in Figure 2. The hypophysis increased virtually in weight, while thyroid was not altered remarkably in weight, but the tendency of a slight decrease was maintained up to the 55 th postoperative day, and thereafter the weight was a little higher than that in normal controls of the respective days of age. The period from 60 to 180 days following the castration made a peak in the growth of thyroid weight. The chronical phase of castration no longer resulted in the significant reduction in weight of thyroid. The adrenal tended to commonly increase a little in weight, and the elevation was insignificant.

\section{Changes in the anterior lobe of pituitary}

The histological finding of the anterior lobe cells in normal rats of variable days of age were almost analogous, so far as the environmental condition was standardized. According to the preparations stained combinedly with PAS and iron hematoxylin, it was learned in all normal control rats that the PAS-positive basophile cells consist of two kinds of type: One is spherical and includes Golginegative-ring, identifiable to be $G$, and the other is either polygonal or spindleshaped, regarded as T. As seen in Figure 3 (90 days of age normal control rat), 


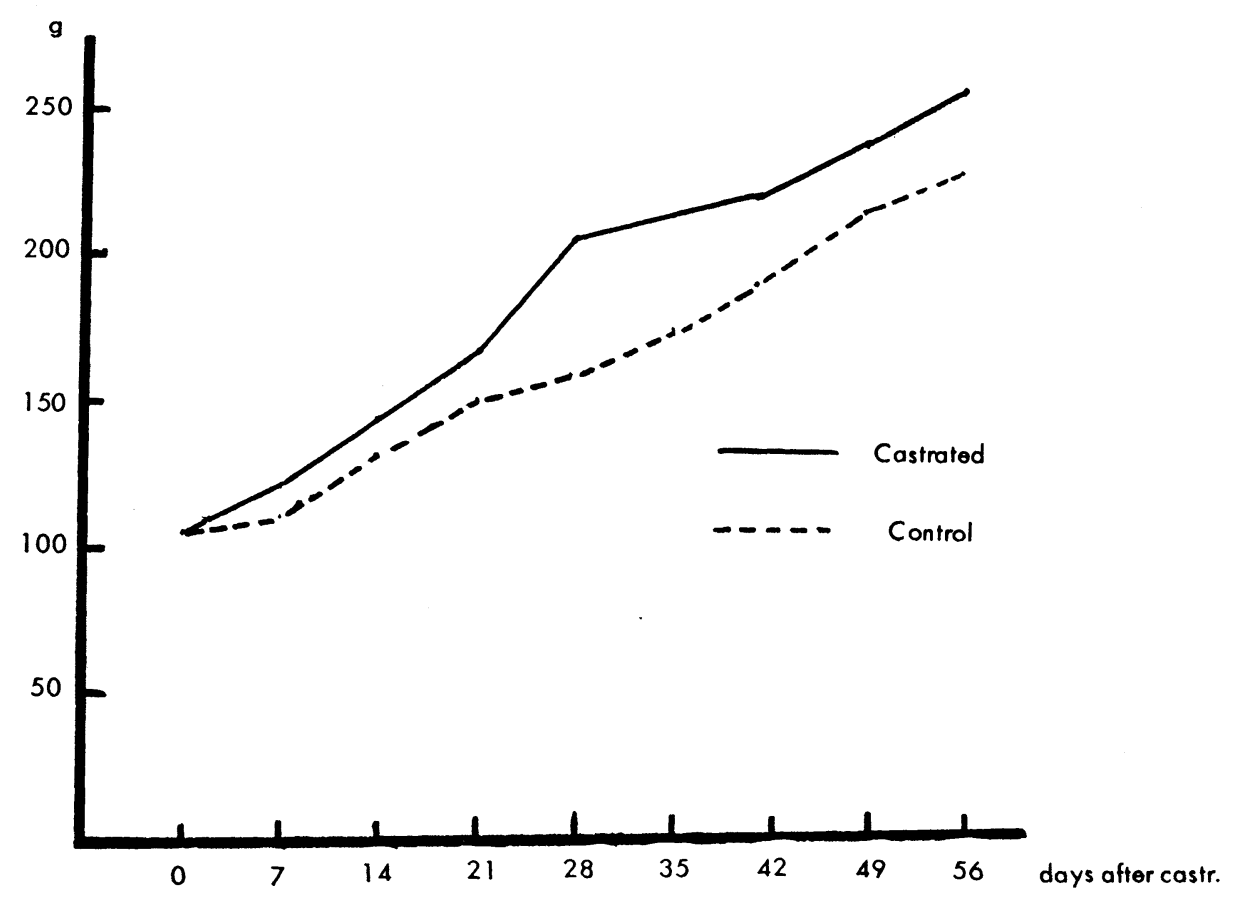

Fig. 1. Increase in body-weight of control and castrated rats, operated at the 45 th day of age

it can be understood that there are numerous intermediate steps between $G$ and $\mathrm{T}$, the assigment of which is not established in shape whether they belong to $\mathrm{G}$ or T. The distribution of both cells does not vary with the central and peripheral area. So-called sex zone, where the basophile cells were concentrated, was in adherence to the intermediate lobe, and was not occupied singly by $\mathrm{G}$, but mingled with both cell types. In the various areas of adenohypophysis, acidophile cells were scattered (Fig. 1), associated with the basophile cells. Acidophile cells were small spherical or oval strongly stained with iron hematoxylin. It needs here to remember the mode of the distribution, shape and size of both acidophile and basophile in the control rats with an aim of making the accurate estimation for the modifications caused by the castration. Figure 4 illustrates the picture of central portion of anterior lobe in the control rats, 90 days of age, stained combinedly with PAS and methylblue. In this figure, two kinds of basopile cells, PAS-red and PAS-purple (arrow), were most distinctive. The former is spherical G-typed and the latter is polygonal T-typed. This staining ability of basophile cell is contradictory to that demonstrated by Wilson and Ezrin (1954), who pointed out that T is PAS-red and G PAS-purple. Our consideration on the stainablitity on methylblue is such that it is conditioned on the density of the ground substances of the cell-body, and the PAS-purple substance may not stand for the reliable histochemical nature due to containing 


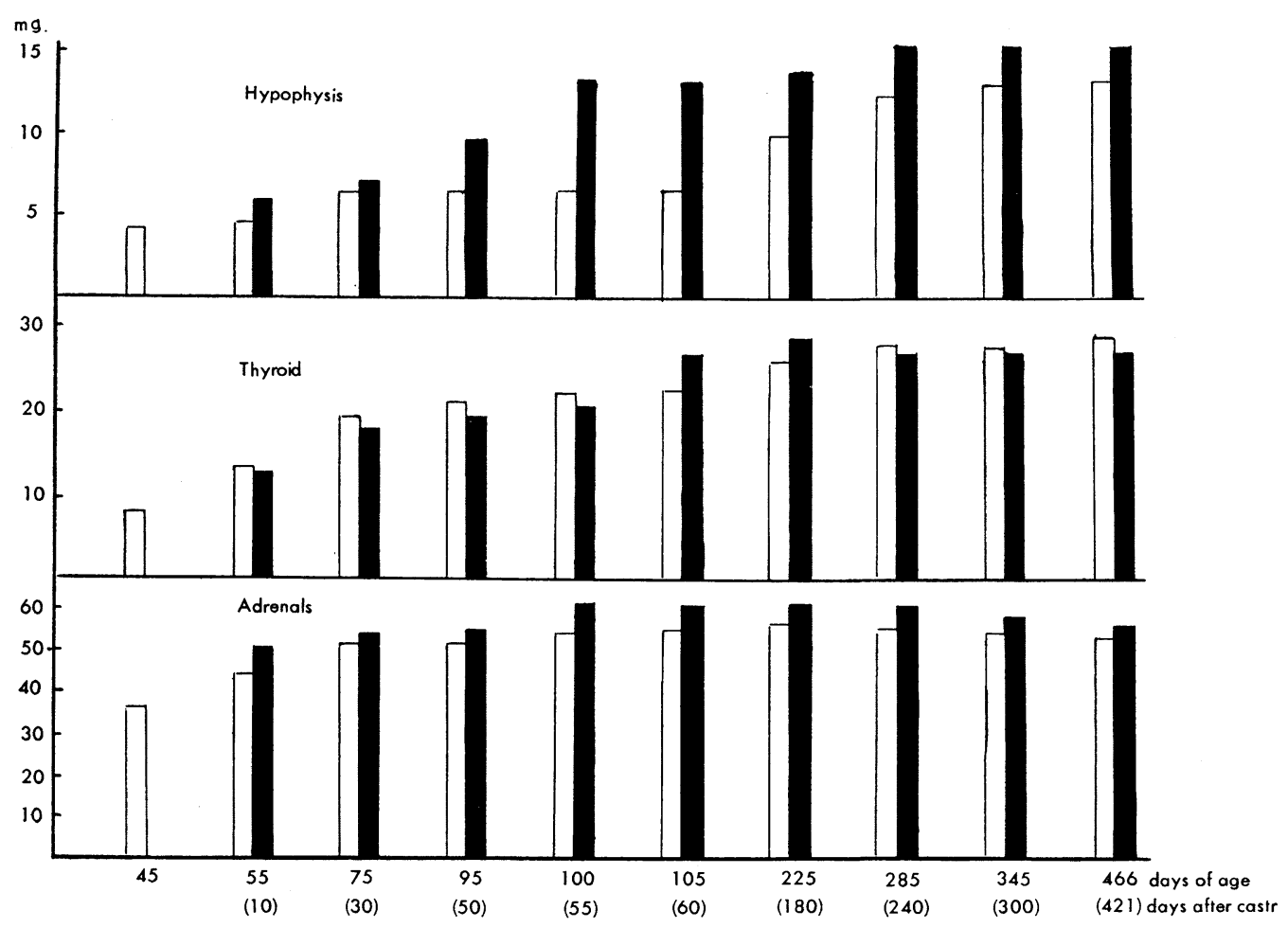

Fig. 2. Changes in organ-weight of hypophysis, thyroid and adrenals. White bar is in control and black one in castrated rats.

hormone. The present observation resulted in a diminished confidence on the aforementioned view that PAS-red spherical cells are situated at the periphery. As is understood obviously in Figure 4, two types of the basophile mingle there. Figurs 5 was according to the Bouin fixed and AF stained preparation of the normal control rat of 90 days of age: AF-positive cells were exclusively polygonal T-typed, and spherical G-typed cells were either negative or weakly positive with AF. This finding is identical with that of Halmi (1950) and Purves and Griesbach (195la and b). It was suggested that AF-positive cells are involved in the high density of cytoplasm concerned with less activation or resting phase.

The castration made the precise increase in number of basophile cells. Ten days after the castration, the response was not progressive yet, but within 45 to 60 days, the hypertrophy and proliferation of them was prominent (compare Fig. 1 with Figs. 6 and 7). It is noted that all proliferated basophile cell-elements became spherical without an exception, and usually contained the enlarged Golgi-ring. The maximum cell diameter was 1.5 to 2 times of abnormal condition. This accounts for the augmentation of cell-function. The hypertrophied basophile cells may be nothing but so-called castration cell denominated by Addison (1917). In the cytoplasm positive with PAS, numerous granules ( $\beta$-granules) stained with 
iron hematoxylin were discernible, in addition to the mitochondria. In the normal rat, the $\beta$-granules were too delicate to be recognized with the light microscopy, but they came to be visualized following the castration. Occasionally there were several number of castration cells occupied by the large colloid mass, equivalent to signet-ring cell. In Figures 6 and 7, T-typed polygonal bosophiles of high density linked with less active function disappeared or were at least negligible. Thus the castration actually made all basophile cells to turn into G-typed cells. In Figure 8, PAS-methylblue stained, 60 days after the castration, a few number of PAS-purple cells infrequently occured (arrow); the peripheral cytoplasm of signet-ring cell was high in density on account of the pressure of intracellular colloid mass $(\downarrow \downarrow)$. Within 300 to 425 days, most basophile cells were full of huge colloid masses, in which even the circumference vacuoles frequently took places, making an impression like a follicle of thyroid gland (Fig. 9). Various stages in the transformation from the initial spherical G-typed cell including the typical Golgi-ring to the mature large signet-ring cell containing the huge colloid mass were demostrated in the figures. Especially the persistent castration resulted in the accumulation of coarse $\beta$-granules taking places in the basophile cells (Fig. 13). According to PAS-methylblue stained preparation, evidences were present that PAS-purple cells grew surely in number (see Fig. 10) and PAS-red Gtyped cells turned into PAS-purple castration cells, which is in good contrast with the high density of T-typed cells (PAS-red) even under the normal condition (Fig. 4). Hence, the definition that a T-typed cell is only PAS-purple should be modified in some sense, because the staining aspect of G-typed cells on methylblue became opposite during the castration. This may depend upon the celldysfunction or exhaustion following the prolonged vain elaboration in secretory activity subsequent to the removal of the target organs. On the other hand, in the end phase of castration acidophile cells were much or less atrophic, and the distribution density of them became lower throughout the whole area of the anterior lobe.

\section{Changes in thyroid gland}

It was learned in above observation on the anterior lobe of pituitary that following the prolonged castration all basophile cell-elements ( $\mathrm{T}$ and $\mathrm{G}$ ) are transformed into hyperfunctional G-typed cells, and T-typed ones usually disapper. If TSH is discharged from $\mathrm{T}$, the loss of it will naturally be followed by the atrophy of thyroid. However, the thyroid did not show any mean reduction in organ weight (c.f. Fig. 2). The histological picture of the normal control thyroid (90 days of age) was demonstrated in Figure 9. The central area of thyroid consists of comparatively smaller follicles whose epithelium are higher than that in the large ones existing at the peripheral area. The size of the follicles, the height of epithelium, the frequency of circumference vacuoles in luminal colloid and the number of colloid droplets in the epithelial cells were measured quantitatively in the normal control. The mean value of measurements was shown in Table 1. Up to the postoperative 60 days, marked histological affections did not follow yet (Fig. 12); as the matter of fact, the follicles never fall into atrophy, representing the normal pattern. However, over the 300 th postoperative day, the luminal colloid 
Fig. 3. Normal control, 90 days of age, Levi, PAS-iron hematoxylin

Fig. 4. Normal control, 90 days of age, Levi, PAS-methylblue

Fig. 5. Normal control, 90 days of age, Bouin, aldehyde fuchsin

Fig. 6. 45 days after the castration, operated at the 45 th day, Levi, azan

Fig. 7. 60 days after the castration, Levi, PAS-iron hematoxylin

Fig. 8. 60 days after the castration, Levi, PAS-methylblue

Fig. 9. 421 days after the castration, the central area of the anterior lobe of pituitary, Levi, PAS-iron hematoxylin

$600 \times$

Fig. 10. 300 days after the castration, the central area of the anterior lobe, Levi, PAS-methylblue $600 \times$

Fig. 11. Normal control, 90 days of age, the central area of thyroid gland, Levi, PAS-iron hematoxylin

Fig. 12. 60 days after the castration, the central area of thyroid gland, Levi, PAS-iron hematoxylin

$285 \times$

Fig. 13. 300 days after the castration, the central area, Levi, PAS-iron hematoxylin $285 X$

Fig. 14. 300 days after the castration, adrenal cortex, Levi, iron hematoxylin 
Plate 1

All photomicrographs showed the central area of the anterior lobe of pituitary of male rats with or without the castration, and were exclusively of 600 magnification.
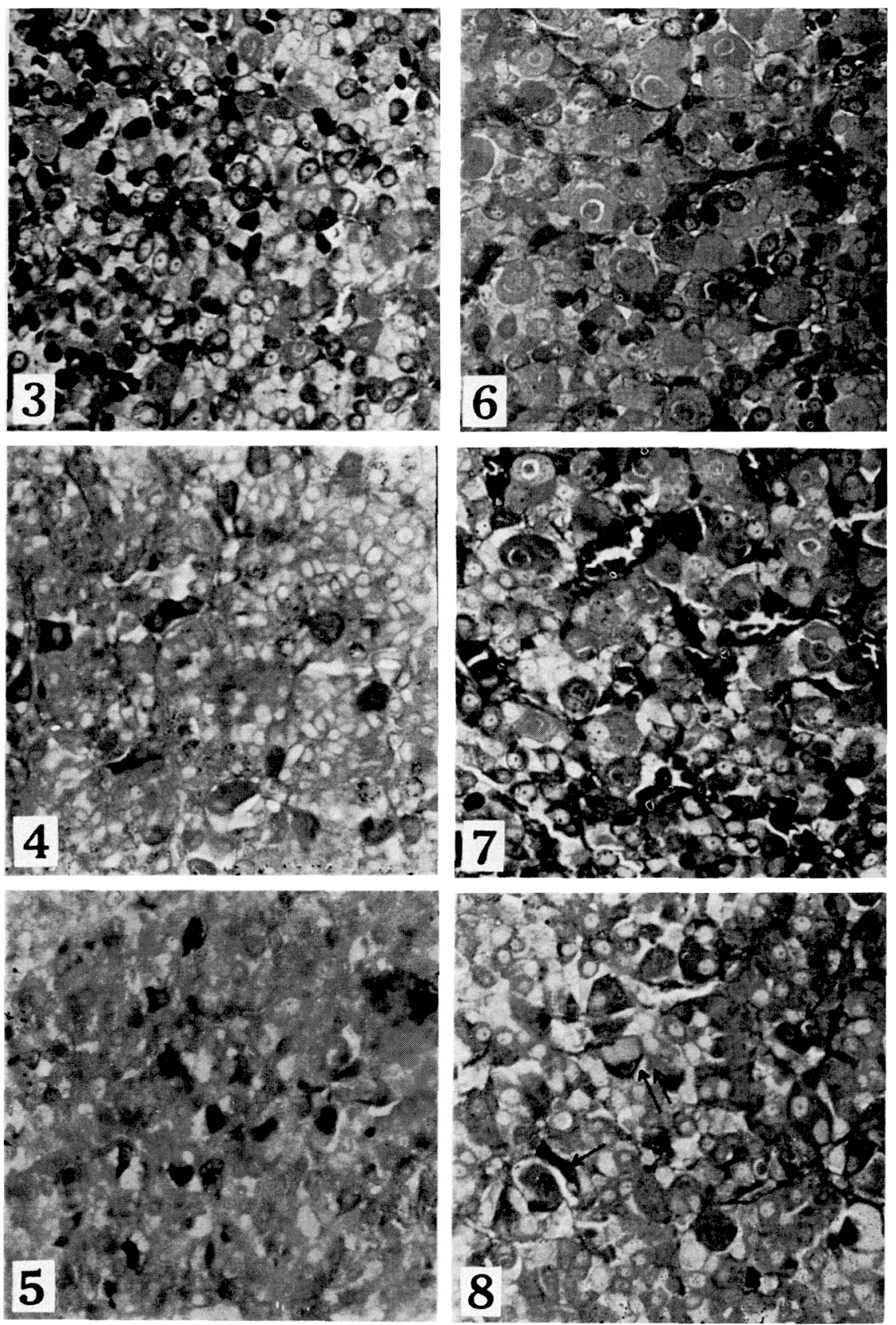

(Reference is made to detail in the main article.) 
Plate 2

All photomicrographs were taken with the materials of male rats castrated at the 45 days of age.
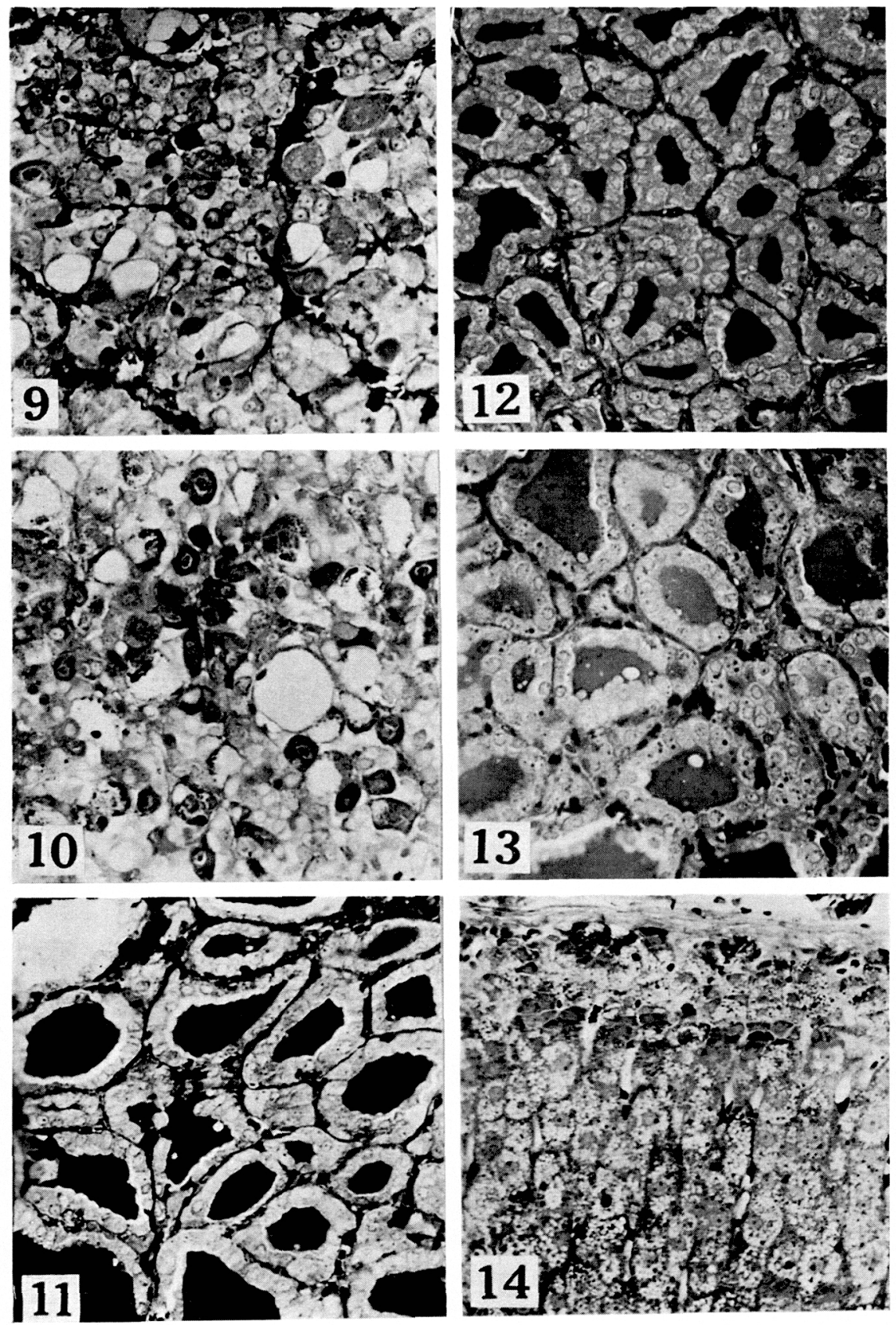
became low in density, weakly stained with iron hematoxylin, where numerous circumference vacuoles appeared; coarse colloid droplets ( $1 \sim 4 \mu$ in diameter) increased remarkably (Fig. 13). The cytoplasmic dome protruding itself into the lumen was frequently seen, which was presumably followed by the apocrine secretion. The circumference vacuoles may be derived from the separation of the cytoplasmic processes. This picture is similar to the thyroid stimulated by TSH administration. The changes in four major indices to show the function of thyroid (Table 1) account for the cell acceleration, being inconsistent with the loss of $\mathrm{T}$. Since the production of thyroxine is stimulated by the hyperrelease of TSH from the hypophysis, G-type of bosophile (castration cell) will naturally secrete a large amount of TSH. From the point of view of this connection, it is harzard to appreciate the current idea that G secretes GTH, while T does independently TSH. The monism that TSH and GTH are together secreted from a single basophile cell is therefore tenable. The monism was proposed by Catchpole (1949) to which has been paid less attention.

\section{Changes in adrenal cortex}

The affection of castration to the histological changes of adrenal cortex was reported by many investigators. The alteration in the inner zone of the cortex (zona reticularis or X-zone) of mice was noted emphasizedly in dealing with the secretion of androgen (c.f. Jones, 1957), but in rats the changes in zona reticularis following the castration is not remarkable (Greep and Jones, 1950), especially in the male the inner fasciculata was thickened, but in the spayed female it declined and the whole zona fasciculata may become smaller (Carter, 1954). Although, in the initial phase of castration the adrenal cortex was provided with the picture of a slight stress, resulting in the increase in adrenal weight, the chronical castration made no sign of stress (Shindo, 1960). The reason why the histological observation must be undertaken on the adrenal cortex in our experiments depends upon a prevalent theory that the basophile cell is a possible sourse of ACTH. As already alluded, since the proliferation and hyperfunction of the basophile cells is the main event in the spayed male rats, it is naturally suspected that a large amount of ACTH is released out from a mass of hypertrophied basophile cells to urge the cortex cells. It was informed by Yoshimura (1954) that, when the male adult rats were exposed under the various stresses, the transitional zone disappears; zona fasciculata extends itself to the capsule, associated with the reduction in width of zona glomerulosa; fat granules decrease in number in the whole area of cortex; granular mitochondria or large lipoprotein granules (stained with iron hematoxylin) increase in number. The spayed rats used in the present experiments showed no sign of hyperfunction in the adrenal cortex, being akin to the normal pattern, in spite of a small increase in organ weight. Figure 14 illustrates the adrenal cortex of rat, 300 days after the castration, in which the dark-shadowy transitional zone was obviously seen. Rather the width of zona glomerulosa seems to increase a little above the normal level, and besides fat granules were extremely abundant. The storage of them may become a cause of a slight increase in adrenal weight. It is suggested in this figure that the adrenal cortex is either within the normal condition or within a slight inhibitory status, 
Table 1. Four major morphological indices showing the thyroid function

\begin{tabular}{lcccc}
\hline \hline & $\begin{array}{c}\text { Total no. of } \\
\text { circumf. vacuo- } \\
\text { les } / 50 \text { follicles }\end{array}$ & $\begin{array}{c}\text { Diameter of } \\
\text { central fol } \\
\text { licles } \\
(\mu)\end{array}$ & $\begin{array}{c}\text { Total no. of } \\
\text { colloid droplets } \\
/ 10 \text { central } \\
\text { follicles }\end{array}$ & $\begin{array}{c}\text { cell-height } \\
(\mu)\end{array}$ \\
\hline 60 days of age & $10 \sim 15$ & 50 & $10 \sim 15$ & 7.6 \\
70 days of age & $10 \sim 15$ & $50 \sim 60$ & $12 \sim 17$ & 7.7 \\
100 days of age & $10 \sim 20$ & $60 \sim 70$ & $10 \sim 16$ & 7.7 \\
castr. 60 days & $20 \sim 25$ & $50 \sim 60$ & $1 \sim 8$ & 7.8 \\
castr. 300 days & $400 \sim 502$ & $40 \sim 51$ & $60 \sim 65$ & 9.2 \\
castr. 353 days & $120 \sim 160$ & $45 \sim 54$ & $400 \sim 510$ & 10.9 \\
castr. 421 days & $5 \sim 10$ & $40 \sim 60$ & $200 \sim 303$ & 9.4 \\
\hline
\end{tabular}

† cell-herght index was the mean value of measurements at 100 follicular gland cells at random (method of Uotila and Kannas, 1952)

Therefore the idea that a basophile cell is a possible site of ACTH could not be highly appreciated by us in reference to the dull response in adrenal cortex so far as the experiment of castration is concerned. Reversely as seen in Figure 14, acidophile cells fell into atrophy and were reduced in number. This is just compatible to the above response on adrenal cortex, and further discussion would wander from the subject in this investigation.

\section{SUMMARY}

Sixty male rats of Wistar-Imamichi strain castrated at the 45 days of age were decapitated at the $10,30,50,55,60,180,240,300$ th and 421 st postoperative day respectively. The anterior lobe of pituitary, adrenal and thyroid were investigated histologically. Commonly, in the control intact rats of various ages, the thyrotroph $(\mathrm{T})$ was polygonal and the gonadotroph $(\mathrm{G})$ spherical, together stained with PAS; with PAS-methylblue stain, T was PAS-purple, while G PAS-red; with aldehyde fuchsin stain, $T$ positive but $G$ negative. The significant proliferation of hypertrophied basophile cell was the main event following the prolonged castration. They belong exclusively to the castration cell. After the 150 th postoperative day, most of them were transformed into so-called signet-ring cells containing the huge colloid mass; when they fell into an exhaustion, they gained the PAS-purple tincture, which may be concerned with the high density of the ground substance of the cell-body. In a moment $\mathrm{T}$ disappeared in the pituitary, the thyroid would be naturally expected to be atrophic. Nevertheless, the fact being contradictory to this expectation, thyroid provided no atrophic pattern, but rather the vigorous chronical response at the same level as by TSH administration. A expedited picture was no longer seen in adrenal cortex. From these observations, a question could naturally arise on the fixed classification of $\mathrm{G}$ and $\mathrm{T}$. The monism is here tenable concerning the TSH and GTH secretion from a kind of basophile cell in the anterior lobe of pituitary. 


\section{REFERENCES}

Addison, W.H.F. (1917). J. Comp. Neurol. 28, 441.

Barrnett, R.J., A.J. Ladman, N.J. McAllaster and E.R. Siperstein (1956). Endocrinology 59, 398.

Carter, S.B. The Influence of Oestrogen on the Adrenal Gland of the Female Rat. Ph.D. Thesis, Univ. of Birmingham, p. 18 (1954).

Catchpole, H.R. (1949). J. Endocrinol. 6, 218.

Greep. R.O. and I.C. Jones (1950). Recent Progr. in Hormone Research 5, 147.

Halmi, N.S. (1950). Endocrinology 47, 289.

Halmi, N.S. (1952). Stain Technol. 27, 61.

Jones, I.C. The Adrenal Cortex. Cambridge Univ. Press, p. 102 (1957).

Marshall, J.M. (1951). J. Exptl. Med. 94, 21.

Purves, H.D. and W.E. Griesbach (1951a). Endocrinology 49, 427.

Purves, H.D. and W.E. Griesbach (1951b). Ibid. 49, 652.

Purves, H.D. and W.E. Griesbach (1955). Ibid. 56, 374.

Reese, J.B., A.A. Koneff and P. Wainman. Essays in Biology. Berkeley, Univ. of California, p. 473 (1943).

Rennels, E.G. (1956). Anat. Record 124, 351.

Rennels, E.G., J.E. Hildebrand and J.C. Finerty (1956). Ibid. 125, 594.

Shindo, M. (1960). Clinical Endocrinology 8, 673. (In Japanese)

Uotila, U. and C. Kannas (1952). Acta Endocrinol. 11, 49.

Yoshimura, F. (1954). Endocrinol. Japon. 1, 177.

Wilson, W.D. and C. Ezrin (1954). Am. J. Pathol. 30, 891. 